\title{
ARTYKULY \\ RUMUŃSCY ARUMUNI I ICH JĘZYK
}

\author{
TOMASZ KLIMKOWSKI
}

ABSTRACT. Tomasz Klimkowski, Rumuńscy Arumuni i ich język (Aromanians of Romania and their language).

Balcanica Posnaniensia. Acta et studia, XIX, Poznań 2012, Wydawnictwo Instytutu Historii UAM, pp. 7-18, ISBN 978-83-63-047-17-7, ISSN 0239-4278. Polish text with a summary in English.

Tomasz Klimkowski, Uniwersytet im. Adama Mickiewicza, Instytut Filologii Romańskiej, Aleje Niepodległości 4, 61-874 Poznań, Polska - Poland.

Po podbojach tureckich na Bałkanach Wołosi południowi, czyli Macedowołosi (Arumuni) i Meglenowołosi, znaleźli się w granicach Imperium Osmańskiego, na obszarach zdominowanych kulturowo i językowo przez Greków, Słowian i Albańczyków. W związku z tym nie wykształcili własnej świadomości narodowej, w przeciwieństwie do Wołochów północnych, czyli Rumunów, którym udało się zorganizować i utrzymać narodowe państwa, stanowiące oparcie dla rozwoju rodzimej kultury i języka. Jako etnos podatny pod tym względem na zaanektowanie przez innych, Wołosi stali się przedmiotem akcji propagandowych z różnych stron. Do walki o rząd ich dusz pierwsi ruszyli Grecy, którzy w XVIII zaczęli prowadzić na szeroką skalę hellenizację Wołochów w podległych greckiej Cerkwi szkołach, wychowując ich na „dobrych greckich patriotów". W XIX w. do rywalizacji z Grekami stanęli Rumuni. Na skutek zabiegów dyplomacji rumuńskiej u Wysokiej Porty w 1864 r. otwarto pierwszą szkołę w Macedonii z językiem ojczystym Wołochów jako wykładowym. Ponieważ w przekonaniu Rumunów i prorumuńskich Wołochów arumuński i meglenicki stanowiły południowe dialekty rumuńskiego, lecz same były niedostatecznie ustandaryzowane, w praktyce nauczanie prowadzono w ,dialekcie dakorumuńskim” jako ,jezzyku literackim", czyli po prostu w języku rumuńskim używanym w Rumunii ${ }^{1}$. W ten sposób formowały się kolejne pokolenia Arumunów, którzy po nauce w rumuńskich

${ }^{1}$ M. Caragiu Marioțeanu, Dialectul aromân, w: M. Caragiu Marioțeanu, Şt. Giosu, L. Ionescu-Ruxăndoiu, R. Todoran, Dialectologie română, Bucureşti 1977, s. 174. 
szkołach na Bałkanach podejmowali studia w Rumunii i często zostawali tam już na stałe $^{2}$. Równolegle ze szkołami zakładano rumuńskie cerkwie, choć nie tak liczne jak szkoły, ze względu na opór kontrolujących organizację kultu Greków. W 1905 r. Turcy poszli na kolejne ustępstwo: sułtan Abdülhamid wydał dla Wołochów specjalny dekret (irade), w którym uznawał ich za osobny naród (Ullah millet - 'naród wołoski') i nadawał im takie same prawa jak swoim innym niemuzułmańskim poddanym. Wśród wołoskich patriotów z II połowy XIX i początków XX w. dominowały zatem nastroje prorumuńskie i protureckie. Ich świadectwem jest wyznanie działacza arumuńskiego Apostola Mărgărita (1836 - 1903):

Întâiul nostru interes, al Armânilor, este mântuirea Imperiului Otoman. Noi nu sperăm să ne unim mâne cu frații noştri din România: suntem despărțiţi de dânşii prin principate şi regate... O crisă orientală ne-ar da în mânile Sârbilor, Grecilor sau Bulgarilor, popoare creştine şi civilisate, cari, ținându-ne deja prin comunitatea de religiune, ar voi să ne ție şi prin comunitatea de limbă, ne-ar închide şcoalele, ne-ar risipi comunitățile ${ }^{3}$.

Dni Imperium były już jednak policzone. Wojny bałkańskie z lat 1912-1913 odebrały mu prawie wszystkie europejskie posiadłości, przynosząc Wołochom to, czego tak bardzo się obawiali: podział i wynarodowienie. Nic więc dziwnego, że zapamiętali je oni jako największą katastrofę w swoich dziejach. Od końca średniowiecza żyli wszyscy w jednym państwie - Imperium Osmańskim. Pierwszy wyłom dokonany został w 1881 r. na skutek przyłączenia do Grecji Tesalii, co podzieliło Arumunów między Grecję a Turcję. Nic więc dziwnego, że Rumunia sprzeciwiała się temu i że protestowali również sami Arumuni w petycji przesłanej uczestnikom Kongresu Berlińskiego. Po wojnach bałkańskich, tj. po powstaniu Albanii i podziale Macedonii, Arumuni znaleźli się w granicach czterech państw: Grecji, Albanii, Serbii i Bułgarii, a bliscy im językowo Meglenowołosi - dwóch: Grecji i Serbii. Wprawdzie na pokoju bukareszteńskim Grecja, Bułgaria i Serbia zobowiązały się respektować prawo Wołochów do własnych szkół i cerkwi, jednak Serbia zaczęła je

\footnotetext{
2 Pierwszą ważniejszą emigrację arumuńską tworzyły elity wołoskie, które po utracie „,arumuńskiego raju", Moskopola na terenie dzisiejszej Albanii, osiadły w granicach Austro-Wegier: w Budzie, Peszcie czy Wiedniu. Tam po raz pierwszy na większą skalę zadziałał mechanizm, symptomatyczny dla dwóch ostatnich wieków - zetknięcie z Rumunami uświadamiało Wołochom wzajemną bliskość językową i wyzwalało poczucie wspólnoty, tak jak w przypadku archimandryty Averchie z góry Athos, który w 1862 r. wykrzyknął na defiladzie wojskowej w Bukareszcie „Şi eu hiu armân!” (,Ja też jestem Arumunem!”, co w tym kontekście należałoby thumaczyć raczej jako „Ja też jestem Rumunem!”) - Părintele Averchie, w: S. Diamandi, Oameni şi aspecte din istoria aromânilor, Bucureşti 1940, s. 301.

3 „Naszym najpierwszym interesem, interesem Arumunów, jest ocalenie Imperium Osmańskiego. Nie mamy nadziei na to, że zjednoczymy się jutro z naszymi braćmi w Rumunii: jesteśmy oddzieleni od nich tyloma księstwami i królestwami... Kryzys wschodni wydałby nas w ręce Serbów, Greków lub Bułgarów, chrześcijańskich i cywilizowanych narodów, które - zawładnąwszy już nami poprzez wspólnotę wyznania - chciałyby zawładnąć nami również poprzez wspólnotę języka, zamknęłyby nam szkoły, rozproszyły nasze wspólnoty." (tłum. cytatów z j. rumuńskiego T. Klimkowski) - cyt. za E. Tircomnicu, Macedoromânii, http://www.etnologia.ro/albania_macedoromanii.php, dostęp: 15.10.2012.
} 
zamykać już w 1914 r., a Bułgaria i Grecja zlikwidowały je wszystkie przed końcem II wojny światowej ${ }^{4}$.

\section{Emigracja Wołochów do Rumunii}

W nowej sytuacji najbardziej ciążyło Wołochom obywatelstwo greckie. Grecy nie uznawali żadnych mniejszości poza turecką, którą zresztą wymienili wkrótce na ludność grecką z Azji Mniejszej. Wołosi, Albańczycy i Słowianie byli dla nich jedynie zromanizowanymi, zalbanizowanymi i zeslawizowanymi Grekami. Kiedy po wielkiej wojnie sytuacja stała się jeszcze bardziej napięta, wspomniana właśnie wymiana ludności między Turcją a Grecją, przewidziana w pokoju lozańskim, podsunęła Wołochom pomysł opuszczenia Grecji i osiedlenia się w Rumunii. Rząd rumuński sugerował takie rozwiązanie już w 1920 r., ale dopiero w listopadzie 1924 r., na pierwszym kongresie Arumunów greckich w Werii (starożytna Berea), myśl tę podjęło szersze grono samych zainteresowanych. W Bukareszcie przebywała już wtedy delegacja arumuńska ze Steriu Hagigogu, synem naczelnika okręgu Weria, Toli Hagigogu, występującym w imieniu „,narodu rumuńskiego w Macedonii” o zgodę na osiedlenie się w tzw. Nowej Dobrudży, czyli Dobrudży Południowej, zdobytej na Bułgarach w II wojnie bałkańskiej i zamieszkałej głównie przez Turków i Tatarów. W czerwcu 1925 r. minister rolnictwa Alexandru Constantinescu przedłożył Radzie Ministrów dokument, zgodnie z którym „Rumuni macedońscy” mieliby osiedlić się w Nowej Dobrudży, jak tylko otrzymają obywatelstwo rumuńskie, ponieważ Konstytucja z 1923 r. zakazywała kolonizowania kraju ludnością obcego pochodzenia. Pierwszy transport kolonistów przypłynął do Rumunii, do Konstancy, w październiku 1925 r. statkiem „Iaşi”. Za nim przybyły następne: z Grecji, Albanii, Bułgarii i Serbii. W grudniu 1925 r. odbył się drugi kongres w Werii, który zapoczątkował kolejną falę kolonizacyjną. Cała akcja zakończyła się w 1933 r. W jej wyniku w Dobrudży Południowej osiedliło się ok. 5 tysięcy rodzin arumuńskich ${ }^{5}$. Równolegle proces ten objął niecałe 400 rodzin meglenowołoskich z 6 wsi na północy Grecji, które w 1926 r. również wyemigrowały do Dobrudży Południowej. Jedni i drudzy uciekali nierzadko przed jawnymi prześladowaniami Grecy palili rumuńskie szkoły i cerkwie, zakazywali wywieszania rumuńskiej flagi. Wyjeżdżając, Meglenici krzyczeli: „Trăiască România!” [„Niech żyje Rumunia!”]

Po akcjach przesiedleńczych z lat 20. i 30. struktura etniczna Macedonii, Epiru i Tesalii uległa znacznym zmianom. Napływ ludności greckiej z Azji Mniejszej i od-

${ }^{4}$ C. Papanace, L'origine et la conscience nationale des Aroumains, Roma 1955, za wersją rumuńską Originea şi conştiința națională a aromânilor, dostępną na stronie projektu Avdhela - http://www.pro iectavdhela.ro/pdf/constantin_papanace_originea_si_constiinta_nationala_a_aromanilor.pdf, dostęp 15.10. 2012, s. 9-10.

5 Aromânii, http://www.infodobrogea.ro/arta-si-cultura/mozaic-cultural/aromanii-din-dobrogea/, dostęp: 15.10 .2012 .

${ }^{6}$ D. Cobuz, Meglena, ingropată, http://www.9am.ro/stiri-revista-presei/2006-06-18/meglena-in gropata.html, dostęp: 15.10.2012. 
pływ ludności wołoskiej do Rumunii pogorszył sytuację pozostałych tam Wołochów, których odsetek spadł znacząco. Pindos przestał być krajem Arumunów, Wielką

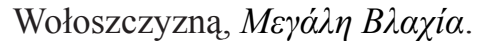

Nową Wielką Wołoszczyzną nie stała się też jednak Dobrudża Południowa. W 1940 r., na mocy układu w Krajowej, Rumunia oddała tę krainę Bułgarii i zgodziła się na wymianę ludności. W ten sposób Arumuni i Meglenowołosi zostali przesiedleni do Dobrudży Północnej (ci drudzy zajęli opuszczoną przez Bułgarów wieś Cerna).

\section{Emigracja arumuńska w Rumunii}

W ten sposób, na skutek wojen bałkańskich z lat 1912-1913, w Rumunii osiedliła się spora grupa Wołochów, w ogromnej większości Arumunów. Nie była to pierwsza emigracja arumuńska w Rumunii (przypomnijmy intelektualistów rumuńskich pochodzenia arumuńskiego z poprzednich pokoleń), ale pierwsza o charakterze masowym. Do pierwszego pokolenia Arumunów wychowanych i wykształconych lub nawet urodzonych w Rumunii należeli m. in.: Vasile Barba (1918 - 2007), Apostol Caciuperi (1920 - 1995), Tiberiu Cunia (ur. 1926), Matilda Caragiu Marioțeanu (1927 - 2009), Hristu Cândroveanu (ur. 1928), wybitni intelektualiści i działacze arumuńscy. Ich losy są reprezentatywne dla całego pokolenia, pomijając oczywiście tych Arumunów, którzy ulegli całkowitej asymilacji, jak aktor Toma Caragiu, brat Matildy, o ogromnych zasługach dla kultury rumuńskiej, ale zupełnie niezwiązany z kulturą arumuńską 7 Barba, Cunia, Caciuperi i Caragiu Marioțeanu urodzili się jeszcze w Grecji, w Macedonii Egejskiej, odpowiednio w Megala Liwadia (arum. Giumala di Nghios), Edessa, Awdella (arum. Avdhela) i Argos Orestiko (arum. Hrupishti). Pod koniec lat 20. ich rodziny przeniosły się do Dobrudży Południowej (tzw. Nowej Dobrudży, zdobytej na Bułgarii po II wojnie bałkańskiej). Już w Dobrudży, w miejscowości Babuc w okręgu Durostor, urodził się Hristu Cândroveanu. W 1940 r., po oddaniu Dobrudży Południowej Bułgarom, wszyscy przenieśli się do Dobrudży Północnej lub jeszcze dalej, w głąb Rumunii.

W odniesieniu do tego pierwszego pokolenia Arumunów rumuńskich można mówić, przynajmniej początkowo, o istnieniu wspólnej tożsamości narodowo-etnicznojęzykowej. Wszyscy uznawali się za Rumunów, ale za Rumunów południowodunajskich, łącząc $w$ ten sposób rumuńską tożsamość narodową z poczuciem przynależności do wspólnoty arumuńskiej. Arumuński uważali za jeden z czterech dialektów rumuńskich, drugi pod względem zasięgu i prestiżu kulturowego, przy czym językiem literackim był dla nich dialekt ,dakorumuński”. W związku z tym, dla zapisu ojczystego dialektu używali standardowego alfabetu rumuńskiego z dodatkiem kilku znaków dla oddania dźwięków nieznanych językowi literackiemu.

\footnotetext{
7 Poza jednym chyba epizodem: recytacją wiersza Constantina Belimace (1848 - 1928) „Dimândarea părintească”, uważanego za „hymn Arumunów”.
} 
Z biegiem czasu, między Arumunami rumuńskimi zaznacza się coraz większa rozbieżność poglądów na kwestię ich tożsamości. Choć można by się spodziewać, że w czasie reżimu Ceauşescu nie bardzo miała rację bytu postawa alternatywna do opisanej powyżej, wtedy już w pewnym stopniu tradycyjnej, bo niemal dwuwiekowej, na przełomie lat 70. i 80. Vasile Barba publikuje szereg tekstów8 postulujących uznanie Arumunów za mniejszość narodową we wszystkich krajach, w których żyją, oraz wprowadzenie ich języka do szkół, Cerkwi, prasy, radia i telewizji. W $1983 \mathrm{r}$. Barba wyjeżdża do RFN, do Fryburga, gdzie zakłada organizację Uniunea trâ Limbâ shi Culturâ Armâneascâ, organizującą kongresy arumuńskie, oraz pismo „Zborlu a nostru" [,Nasze słowo”]. W tych działaniach sekunduje mu inny emigrant, Tiberiu Cunia. Drogi tradycjonalistów i grupy Barby rozchodzą się ostatecznie z powodu używania przez tych ostatnich, m. in. w „Zborlu a nostru”, osobnego alfabetu, nazywanego przez ich przeciwników „barbar” ('barbarzyński' - aluzja do nazwiska Barby) lub „scrierea cuniaformă” (przekształcone „scrierea cuneiformă” - 'pismo klinowe', aluzja do nazwiska Cunii). Należy nadmienić, że alfabet ten - wbrew temu, co się sądzi - nie jest bynajmniej nowy, gdyż opiera się na alfabecie zastosowanym przez Mihaia Boiagiego w pierwszej gramatyce arumuńskiej z 1813 r. ${ }^{9}$, a ten z kolei - na jednym z wariantów alfabetu łacińskiego używanego przez rumuńską Szkołę Siedmiogrodzką.

W samej Rumunii po wyjeździe Barby panuje niepodzielnie stanowisko tradycyjne. Po 1989 r. sytuacja niewiele się zmienia. Wychodzące w Rumunii pismo arumuńskie „Deşteptarea” [,Przebudzenie”] z dodatkiem „Dimîndarea” [,Zew”] oraz działające tam organizacje arumuńskie: Societatea de Cultură Macedo-Română [Towarzystwo Kultury Macedorumuńskiej, powstałe w 1860 r.], Picurarlu de la Pind [Pasterz z Pindosu], fundacja i wydawnictwo „Dimîndarea părintească” [,Zew ojców”] ${ }^{10}$ mają charakter wybitnie konserwatywny. Poglądy tradycjonalistów dobrze wyrażają słowa Hristu Cândroveanu, dyrektora pisma oraz większości powyższych instutucji:

Aromânii, prin urmare, sunt români şi vorbesc un dialect românesc. Dincolo de acest adevăr nu există decât discursuri politice de neluat în seamă, sau neştiință, confuzie regretabilă din lipsa de informare ştiințifică, în cel mai bun caz ${ }^{11}$.

Noi nu suntem minoritate. Suntem români şi vrem să rămânem români ${ }^{12}$.

${ }^{8}$ Aromânii: O minoritate națională uitată care îşi revendică drepturile, „Noi Tracii”, $n$ r 2/1978, Włochy.

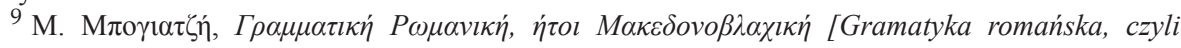
macedowołoska], Bí́vvi 1813.

${ }^{10}$ Nazwa ta stanowi nawiązanie do wiersza Belimace, zob. przyp. 7.

11 „Arumuni są zatem Rumunami i mówią dialektem języka rumuńskiego. Poza tą prawdą są tylko niegodne uwagi dyskusje polityczne lub w najlepszym razie niewiedza, godna ubolewania pomyłka wynikająca z braku informacji naukowej." - H. Cândroveanu, În definitiv - ce sunt macedo-româniil aromânii?, http://istoria.md/articol/81, dostęp 15.10.2012.

12 „My nie jesteśmy mniejszością. Jesteśmy Rumunami i chcemy pozostać Rumunami.” - H. Cândroveanu, Nu suntem o minoritate. Suntem români şi vrem să rămânem români, http://www.poezie.ro/ 
Do dyskusji włącza się Matilda Caragiu Marioțeanu, do tej pory zajmująca się Arumunami i ich etnolektem bardziej jako badaczka niż działaczka. W 1993 r. wychodzi spod jej pióra Dodecalog al aromânilor sau 12 adevăruri incontestabile, istorice şi actuale asupra aromânilor şi asupra limbii lor [Dodekalog Arumunów lub dwanaście niepodważalnych prawd, historycznych $i$ wspótczesnych, o Arumunach $i$ ich ję$z y k u$ ]. Autorka manifestu czyni pewne ustępstwa w stronę nowych tendencji, a ponieważ czasami trudno pogodzić je z tradycyjnymi, prowadzi to do mało logicznych wniosków: arumuński jest dialektem rumuńskiego, ale dla Arumunów funkcjonuje jako język; Arumuni powinni być uznani za mniejszość narodową wszędzie, gdzie żyją w większych skupiskach, jednak traktowanie ich jako mniejszość w Rumunii jest absurdem. Innymi słowy, Arumuni rumuńscy są Rumunami, natomiast Arumuni z innych krajów nie są już Rumunami, lecz Arumunami.

Z drugiej strony, wraz z dojściem do głosu młodszego pokolenia, również w Rumunii ujawnia się obóz określany coraz chętniej przez oponentów jako „separatystyczny". Tworzą go organizacje: Comunitatea Aromână din România [Wspólnota Arumunów Rumuńskich] oraz Liga Aromânilor din România [Liga Arumunów Rumuńskich]. Przewodniczący Ligi, Dumitru Piceava (ur. 1941), założył w 1996 r. pismo „Bana armâneascâ” [„Życie arumuńskie”], wychodzące w całości po arumuńsku, w nowej ortografii, oraz jako jeden z pierwszych zaczął mówić o uznaniu Arumunów za mniejszość narodową w Rumunii:

„Limba aromână nu poate să fie socotită ca un dialect al limbii dacoromâne.” (cytat z historyka Alexandru Xenopola) [...] Pentru ca acea populație să poată să rămână ca atare în această perioadă de globalizare, este nevoie de recunoaşterea aromânilor ca minoritate națională. Numai astfel pot fi salvați aromânii ca neam şi pe pământ românesc ${ }^{13}$.

W 1997 r. emigracyjna grupa Barby osiaga ważny sukces - Rada Europy wydaje kontrowersyjne „Zalecenie nr 1333”, zawierające apel do krajów, w których zamieszkują Arumuni, o ochronę arumuńskiego dziedzictwa kulturowego i wprowadzenie języka arumuńskiego do szkolnictwa, kultu religijnego i mediów. Dokument stał się prawdziwą solą w oku Grecji, która w dalszym ciagu neguje istnienie Wołochów i „Zalecenie" porównuje do znienawidzonego irade sułtana z 1905 r. „Zalecenie” demonizuje się również w Rumunii, uznającej oczywiście Arumunów, ale nie za mniejszość narodową. W rzeczywistości „Zalecenie” w ogóle nie porusza tego problemu, dlatego zdaniem „separatystów” nie jest ono wystarczającą gwarancją ich praw. W związku z tym, podejmują oni co jakiś czas próbę przekonania władz rumuńskich do uznania Arumunów za mniejszość narodową. W 2005 r. petycję w tej sprawie

index.php/personals/124731/Nu_suntem_o_minoritate._Suntem_rom $\% \mathrm{C} 3 \% \mathrm{~A} 2 \mathrm{ni} \% \mathrm{C} 5 \% 9 \mathrm{Fi}$ vrem_s\%C4\%83_r\%C4\%83m\%C3\%A2nem_rom\%C3\%A2ni, dostęp $1 \overline{5} .10 .2012$.

$\overline{13}$ „Język arumuński nie może być uważany za dialekt języka dakorumuńskiego.” „Aby ta ludność mogła przetrwać w czasach globalizacji należy uznać Arumunów za mniejszość narodową. Tylko tak można uratować Arumunów jako naród również na ziemi rumuńskiej” - D. Piceava, Un alt punct de vedere asupra aromânilor, ,Bana armâneascâ”, nr 43-44/2006, s. 16-17. 
złożyła Comunitatea Aromână din România, a rok później - Liga Aromânilor din România. Te nie dość że nie przyniosły spodziewanego rezultatu, to jeszcze zaogniły konflikt między tradycjonalistami a separatystami, bowiem od inicjatywy CAR i LAR stanowczo odcięły się: Societatea de Cultură Macedo-Română, Picurarlu de la Pind i Akademia Rumuńska. Zacytujmy fragment repliki Picurarlu z potępiającego petycje listu do prezydenta Traiana Băsescu z 2006 r.:

La 16 aprilie 2005, un grup de compatrioți români - cu ascendențe balcanice, recte aromâni/macedoromâni - a cugetat că nu mai doreşte a fi de naționalitate română; în numele unei ONG, a unei asociații insidios intitulate Comunitatea Aromână din România, respectivii inşi au cerut autorităților române recunoaşterea aromânilor - în România! - ca minoritate naţională. Este un afront antinațional fără precedent, ce agresează istoria, complexă şi tumultuoasă - demnă şi eroică, în egală măsură a ansamblului neamului românesc, carpato-danubiano-balcanic, şi Patriei noastre România ${ }^{14}$.

Od końca minionego wieku ścierają się zatem w Rumunii dwie frakcje arumuńskie. Zdaniem CAR i LAR jedynie uznanie Arumunów za mniejszość stworzy im odpowiednie warunki do zachowania i rozwoju kultury i języka. Ich przeciwnicy twierdzą zaś, że starania te podyktowane są ukrytymi celami politycznymi. Błędem byłoby twierdzić, że „separatyzm” właściwy jest młodszemu pokoleniu, a „tradycjonalizm” starszemu. Równolatek separatysty Piceavy, Nicolae Saramandu (ur. 1941), dyrektor Instytutu Fonetyki i Dialektologii Akademii Rumuńskiej, jest zwolennikiem tradycyjnego podejścia i współautorem, wraz z Matildą Caragiu Marioțeanu, podręcznika do arumuńskiego w ortografii rumuńskiej ${ }^{15}$. Tradycjonalistów nie brakuje również w najmłodszym pokoleniu. Obie grupy są dobrze reprezentowane w Internecie, co sprawia, że konflikt przenosi się również do sieci. Np. internetowa kampania blogu arumuńskiego Zboară niangrâpsiti, zatytułowana Noi suntem aromâni, nu armãnj ${ }^{16}$, jest odpowiedzią na lansowaną przez separatystów nazwę armãn (tak brzmi etnonim 'Arumun' po arumuńsku) zamiast tradycyjnego aromân (w brzmieniu rumuńskim).

14 „16 kwietnia 2005 r. grupa naszych rodaków - Rumunów o bałkańskich korzeniach, to jest Arumunów/Macedorumunów - postanowiła, że nie chce już być narodowości rumuńskiej; w imieniu organizacji pozarządowej, towarzystwa nazywanego przewrotnie Wspólnotą Arumunów Rumuńskich, rzeczeni osobnicy zażądali od władz rumuńskich uznania Arumunów - w Rumunii! - za mniejszość narodową. Jest to bezprecedensowy afront antynarodowy, wymierzony w historię, w równej mierzoną złożoną i burzliwą, co godną i bohaterską, całego narodu rumuńskiego, karpacko-dunajsko-bałkańskiego, i naszej Ojczyzny Rumunii." - Macedoromânii sunt români absoluți, http://www.formula-as.ro/2006/713/ scrisoarea-saptamanii-36/macedoromanii-sunt-romani-absoluti-6915, dostęp: 15.10.2012.

15 M. Caragiu Marioțeanu, N. Saramandu, Manual de aromână. Carti trâ învițari armâneaşti, Bucureşti 2005.

16 https://daimadeadun.wordpress.com/2011/01/08/noi-suntem-aromani-nu-armanj-o-campanie-ablogului-zboara-niangrapsiti/, dostęp: 15.10.2012. 


\section{Rumunizacja języka}

Oba antagonistyczne ugrupowania, mimo ich dobrej, choć różnie rozumianej woli zachowania mowy i kultury przodków, łączy jedno: ich arumuńszczyzna pozostawia coraz więcej do życzenia. Większość rumuńskich Arumunów posługuje się na co dzień rumuńskim, a ci nieliczni, którzy mówią po arumuńsku, znają go tylko do pewnego stopnia. W wielu przypadkach jest to arumunizowany fonetycznie standardowy rumuński. Widoczne jest to zarówno w słownictwie, jak i gramatyce i stylu ${ }^{17}$. Stosunkowa „czysta” arumuńszczyzna pisma „Bana armâneascâ” przesycona jest jednak, zwłaszcza w poważniejszych artykułach społeczno-politycznych, słownictwem rumuńskim (na ogół zresztą francuskiego pochodzenia), co z jednej strony jest zjawiskiem nieuniknionym, gdyż arumuński, głównie język codziennej komunikacji, nie ma wystarczająco rozwiniętej leksyki, z drugiej jednak, w naturalnych warunkach rozwoju czerpałby w tym zakresie z greki. Mocno zrumunizowany jest również język publikacji emigranta Apostola Caciuperiego. Niekiedy autor „zapomina” nawet o adaptacji fonetycznej danego słowa, np. w tłumaczeniu Nowego Testamentu ${ }^{18}$ stosuje konsekwentnie rumuńskie $p_{a c} e^{19}$, mimo że w arumuńskim powinno ono funkcjonować w formie patse (por. tsentru, contsertu, detsizie lub nazwę efemerycznego państewka Arumunów z czasów II wojny światowej: arum. Printsipatlu di la Pindu vs. rum. Principatul de Pind), nie mówiąc o tym, że naturalniej brzmiałoby greckie z pochodzenia irine $e^{20} . \mathrm{Z}$ innych rumunizmów leksykalnych uderza użycie dicãt (rum. decât 'niż') zamiast arum. di, np. Atsel cari vine după mine ma putut dicât mine easte (Mt 3, 11) czy da (rum. da 'tak') zamiast tradycyjnego $i e^{21}$, np. Da, eu vin curundu (Ap 22, 20). Skalę problemu, tzn. stopień rumunizacji tekstów arumuńskich pokazuje fakt, że tłumaczenie Ewangelii według Marka autorstwa Caciuperiego, mimo ewidentnych kalk z rumuńskiego, Caragiu Marioțeanu ocenia na tle innych przekładów jako dość udane ${ }^{22}$.

Najbardziej jaskrawym przejawem wpływu rumuńskiego na strukturę gramatyczną arumuńskiego jest użycie przyimka pre/pri (na wzór rum. pe) przed rzeczownikami osobowymi w funkcji dopełnienia bliższego oraz przyimków tu lub la jako wykładni-

17 Wpływ rumuński (,dakorumuński”) na arumuński badała Matilda Caragiu Marioțeanu w pracy: Influența dacoromână asupra graiului unei familii aromâne din România, w: Fono-morfologie aromână. Studiu de dialectologie structurală, Bucureşti 1968, s. 186-215.

18 Noulu Testamentu a Domnului a nostru Isus Hristos, przeł. Apostol Caciuperi, Teulada - Palma München, 1967-1969.

19 Pace pojawia się też w „Bana armâneascâ”, por. nr 43-44/2006, s. 28.

${ }^{20} \mathrm{~W}$ tym miejscu wypada się zatem nie zgodzić w wybitną znawczynią problemu, Matildą Caragiu Marioțeanu, która zarzuca Caciuperiemu nadużywanie grecyzmów (M. Caragiu Marioțeanu, Biblia la Aromâni, http://www.proiectavdhela.ro/pdf/biblia_la_aromani.pdf, dostęp: 15.10.2012, s. 8). Należy również zauważyć, że słownik Papahagiego podaje tylko irine, nie rejestrując w ogóle terminu pace/patse. Jest to tym bardziej wymowne świadectwo, jeśli pamiętać, że słownik ten oddaje stan arumuńszczyzny sprzed wojen bałkańskich (T. Papahagi, Dicționarul dialectului aromân, Bucureşti 1963, s. 47).

21 Również w „Bana armâneascâ”, por. wywiad z Neagu Djuvarą, nr 29/2002, s. 18.

22 M. Caragiu Marioțeanu, Biblia, s. 8. 
ków okolicznika miejsca, powszechne np. u Caciuperiego, a zupełnie nieznane autentycznej arumuńszczyźnie, por. Caciuperi: Iară după țe acățtară pri Ioan, viñe Isus tu Galileea $(\mathrm{Mk} 1,14)$ i poprawne: Iară după țe lu-acățară Ioan, viñe Isus Galileea. Na zjawiska te zwrócili już uwagę Caragiu Marioțeanu ${ }^{23}$ i Cândroveanu ${ }^{24}$.

$\mathrm{Z}$ innych elementów, niewymienionych przez Caragiu Marioțeanu ${ }^{25}$, wskażmy: utrzymanie pod wpływem rumuńskim formy dopełniacza-celownika rzeczowników i przymiotników rodzaju żeńskiego, mimo że w arumuńskim zwyciężyła tendencja do zastępowania jej mianownikiem-biernikiem (odmienia się tylko rodzajnik, podobnie jak w rodzaju męskim i tzw. nijakim oraz w liczbie mnogiej), np. cunoashtirea, tsãnearea shi creashtirea a limbiljei shi a culturiljei aromâne ${ }^{26}$ (odmieniony rzeczownik i przymiotnik - kalka), situatsia criticã a limbãljei shi a culturãljei armâ$\boldsymbol{n e s h t i ^ { 2 7 }}$ (nieodmieniony rzeczownik i odmieniony przymiotnik - kalka częściowa), Simpozionlu di Standardizari a Scriariljei Armãneasc $\tilde{a}^{28}$ (nieodmieniony rzeczownik i przymiotnik - poprawnie) oraz brak, jak w rumuńskim, częstej w arumuńskim antycypacji określonego dopełnienia bliższego, np. va nã chirem sh-limba 'zatracimy też język' (bez antycypacji - kalka), nã u misticãm laia limbã 'mieszamy nasz biedny język $^{29}$ (z antycypacja - poprawnie).

\section{Podsumowanie}

Poza Rumunią panują obecnie wśród Arumunów dwie przeciwstawne tendencje. $\mathrm{Z}$ jednej strony Arumuni ulegają asymilacji przez ludność dominującą w kraju zamieszkania, z drugiej zaś - próbują tworzyć osobną świadomość narodową w oparciu o pozostałości tradycyjnej kultury i standaryzowany intensywnie język. Opcja pośrednia, prorumuńska, nie ma już właściwie zwolenników.

Pierwsza tendencja dominuje w Grecji. Tamtejsi Arumuni uważają się w większości za Greków, co jest wynikiem wielowiekowej hellenizacji, rozpoczętej na długo przed rozbiorem Macedonii, a obecnie również złej prasy Rumunii za granicą i greckiego kompleksu wyższości nad Rumunami, Arumuni, bowiem, utożsamiani są tradycyjnie z Rumunami, przez pamięć o rumuńskich szkołach i cerkwiach dla Arumunów w Grecji czasów przedwojennych.

Druga tendencja panuje przede wszystkim w Macedonii. Arumuni macedońscy, może ze względu na bardzo liberalne traktowanie mniejszości przez władze republiki, zagwarantowane przez konstytucję z 1991 r., zaczynają uważać się za osob-

23 M. Caragiu Marioțeanu, Influența, s. 211-212.

24 H. Cândroveanu, Antologie de proză aromână, Bucureşti 1977, s. 15.

25 M. Caragiu Marioțeanu, Influența, s. 202-214.

26 http://ro.wikipedia.org/wiki/Matilda_Caragiu_Mario\%C8\%9Beanu, dostęp: 15.10.2012.

$27 \mathrm{http}: / /$ miris.eurac.edu/mugs2/do/blob.html?type=html\&serial=1048166046039, dostęp: 15.10. 2012.

28 http://www.ctarm.org/wp-content/galerie/2012/04/4.curs_lectsia6_bck.pdf, dostęp: 15.10.2012.

29 M. Caragiu Marioțeanu, Influența, s. 191. 
ny, różny od rumuńskiego naród. Należy zauważyć, że arumuńska inercja kulturalna w czasach Tity była wynikiem zbyt prorumuńskiego nastawienia samych działaczy arumuńskich. Podobno w 1947 lub 1948 r. delegacja Arumunów prosiła Titę o otwarcie szkół z rumuńskim jako wykładowym, lecz ten - obawiając się ingerencji Rumunii w sprawy Jugosławii - zaproponował im szkolnictwo po arumuńsku. Delegacja odmówiła $^{30}$. Obecnie Macedonia jest jedynym krajem, w którym arumuński jest językiem urzędowym. Dotyczy to wprawdzie tylko jednej gminy ${ }^{31}$ (Kruszewo, arum. Crushuva), jednak ma to ogromny wymiar symboliczny. Macedonia stała się światowym centrum arumunizmu, miejscem kongresów arumuńskich, siedzibą organizacji Unia ti culturã-a Armãnjlor dit Machidunii [Unia na rzecz Kultury Arumunów Macedońskich]. W macedońskim Kruszewie wyszedł również podręcznik do arumuńskiego w nowej ortografii ${ }^{32}$.

Wracając do Rumunii - poprzez inicjatywy takie jak „Bana armâneascâ”, ruch CAR i LAR, Arumuni rumuńscy zaczynają włączać się do światowego ruchu arumuńskiego, podkreślającego odrębność Arumunów od Rumunów. Przyszłość pokaże, na ile trwałe okaże się to zaangażowanie. Z czasem Arumuni prorumuńscy ulegną zapewne całkowitej asymilacji, zaś Arumuni-separatyści zostaną w końcu uznani za mniejszość narodową - pytanie tylko, czy faktycznie wykorzystają to do celów innych niż tylko polityczne.

\title{
AROMANIANS OF ROMANIA AND THEIR LANGUAGE
}

\author{
Summary
}

Until 1913, all Aromanians lived in the same state i.e. the Ottoman Empire, on equal terms with the other non-Muslim subjects of the sultan. After the Balkan wars, they did not succeed in forming their own state and they became separated by the new borders of the four countries: Greece, Bulgaria, Serbia and Albania. That quickly led to ethnic and linguistic tensions, especially in Greece, which continued its policy of forced assimilation of the Vlachs. The mass emigration to Romania, considered by many Vlachs as their only real homeland - first to the Southern and then to the Northern Dobruja - saved them from persecutions but did not protect their ethnic, linguistic and cultural distinctness from assimilation.

After having settled in Romania, Aromanians adopted the Romanian identity and language according to the theory that they represented a part of the Romanian nation and their language - a dialect of Romanian. This traditional, pro-Romanian point of view was the only and official one for a half century, until the late 1970s. It still subsists but competes now with a new, opposite point of view, considered and named a "separatist" one. This new point of view envisages the Aromanians to be a separate nation

${ }^{30}$ H. Cândroveanu, Nu suntem o minoritate.

${ }^{31} \mathrm{Lj}$. Ghiorghieva, Crushuva. Limba armâneascâ fu pricunuscutâ ca limbâ ofitsialâ tu comunicatsia di lucru a Consiliului a Comunâljei, „Bana armâneascâ”, nr 1/2 (43/33), 2006, s. 25.

${ }^{32}$ S. Shteriova, G. Costov, Sã-nvitsãm armãneashti (Учиме влашки), Scopia 2007. 
with a distinct language and requires their recognition as a minority group on behalf of the Romanian authorities.

Regarding the linguistic aspect, the Aromanian language used in Romania is strongly influenced by Romanian, both lexically and gramatically. For the Aromanian language, Romanian represents a source of modern life or abstract vocabulary and a model of morphosyntactic structures. As for the linguistic analysis in our present study, it is based on Aromanian-language articles and literary works, translated or original, written by Aromanian intellectuals from Romania (some of whom subsequently having emigrated in the meantime and lived in other countries). 
